Published in final edited form as:

Am J Physiol Regul Integr Comp Physiol. 2004 May ; 286(5): R874-R880. doi:10.1152/ajpregu. 00391.2003.

\title{
The $\mathbf{M}_{2}$ muscarinic receptor mediates in vitro bladder contractions from patients with neurogenic bladder dysfunction
}

\author{
Michel A. Pontari, Alan S. Braverman, and Michael R. Ruggieri Sr. \\ Departments of Urology and Pharmacology, Temple University School of Medicine, Philadelphia, \\ Pennsylvania 19140-5104
}

\begin{abstract}
Bladder muscle specimens from seven patients with neurogenic bladder dysfunction were analyzed to determine whether the muscarinic receptor subtype mediating contraction shifts from $\mathrm{M}_{3}$ to the $\mathrm{M}_{2}$ subtype as found in the denervated, hypertrophied rat bladder. Seven bladder specimens were analyzed from six female and one male patients. Six of the patients had traumatic cervical spinal cord injuries $\left(\mathrm{C}_{4}-\mathrm{C}_{7}\right)$, and the other patient had an $\mathrm{L}_{1}$ congenital myelomeningocele. This was compared with results from bladder specimens obtained from eight organ transplant donors. The affinities of three subtype-selective muscarinic receptor antagonists for inhibition of carbachol-induced contractions were determined. The affinity of the $\mathrm{M}_{3}$ selective antagonists darifenacin or $p$-fluoro-hexahydrosiladifenadol (p-F-HHSiD) was determined in six of the seven spinal injury patient specimens. The affinity was consistent with $\mathrm{M}_{2}$-mediated contractions in four of these six specimens, intermediate between $\mathrm{M}_{2}$ and $\mathrm{M}_{3}$ in one specimen, and within the $\mathrm{M}_{3}$ range in one specimen. The other specimen, tested only with the $\mathrm{M}_{2}$ selective antagonist methoctramine, showed an $\mathrm{M}_{3}$ affinity. In the organ donors, the affinity of p-F-HHSiD was within the $\mathrm{M}_{2}$ range for six of seven specimens, whereas the affinity of darifenacin was within the $\mathrm{M}_{3}$ range for five of six and intermediate between $\mathrm{M}_{2}$ and $\mathrm{M}_{3}$ for the other specimen tested. The affinity of methoctramine in both organ donor specimens tested was within the $\mathrm{M}_{3}$ range. Whereas normal detrusor contractions are mediated by the $\mathrm{M}_{3}$ receptor subtype, in patients with neurogenic bladder dysfunction as well as certain organ transplant donors, contractions can be mediated by the $\mathrm{M}_{2}$ muscarinic receptor subtype.
\end{abstract}

\section{Keywords}

spinal cord injury

\begin{abstract}
BLADDER CONTRACTION during voiding is mediated by the neurotransmitter ACh acting through muscarinic receptors located on urinary bladder smooth muscle cells. At least three subtypes of muscarinic ACh receptors $\left(\mathrm{M}_{1}, \mathrm{M}_{2}\right.$, and $\left.\mathrm{M}_{3}\right)$ can be distinguished based on the actions of relatively subtype-selective antimuscarinic agents. Five subtypes arising from five separate genes are identifiable by molecular techniques (5). Immunologic, functional, and molecular studies indicate that most tissues, including the human bladder, contain a mixture of subtypes. Immunoprecipitation has determined that both $\mathrm{M}_{2}$ and $\mathrm{M}_{3}$ receptor proteins are present in the human bladder (49); however, affinities of subtype-selective antimuscarinic agents for inhibition of bladder contractions in neurologically intact animal models, including rat, rabbit, and mouse, are consistent with the $\mathrm{M}_{3}$ subtype mediating contraction
\end{abstract}

Copyright (C) 2004 the American Physiological Society

Address for reprint requests and other correspondence: M. R. Ruggieri, Sr., Director of Urologic Research, Temple Univ. School of Medicine, 3400 N. Broad St., 715 OMS, Philadelphia, PA 19140-5104 (rugg1@ msn.com).. 
under normal conditions in vitro $(11,23,29,44)$. In the rat, the potency of subtype-selective antagonists for inhibition of bladder contraction in vivo correlates better with their affinity at $M_{2}$ than at $M_{3}$ receptors (29). The affinities of subtype-selective antimuscarinic agents for inhibiting in vitro human bladder contractions have only been published in a few studies using a very small number of specimens $(18,24,30,36,37)$. These studies also conclude that, although the $\mathrm{M}_{2}$ receptor subtype predominates, the minor population of $\mathrm{M}_{3}$ receptor subtypes mediates contraction of the normal human bladder.

Denervation and spinal cord injury in the rat induce bladder hypertrophy and a change in muscarinic receptor subtype mediating urinary bladder contraction from $M_{3}$ to $M_{2}(7,11)$. Bladder muscle specimens from patients with spinal cord injury were analyzed to determine whether in humans with neurogenic bladder, the muscarinic receptor subtype mediating contraction also shifts from $\mathrm{M}_{3}$ to the $\mathrm{M}_{2}$ subtype.

\section{MATERIALS AND METHODS}

Studies were performed with approval of the Temple University School of Medicine Institutional Review Board and informed consent was obtained from all subjects in this study. At the time of open reconstructive surgery, $5 \mathrm{~mm} \times 15 \mathrm{~mm}$ full thickness muscle specimens were removed from the bladder dome. A total of seven bladder specimens was analyzed from one male and six female patients. Patient characteristics are listed in Table 1. Six of the patients had traumatic cervical spinal cord injuries $\left(\mathrm{C}_{4}-\mathrm{C}_{7}\right)$ with an average time after injury of $2.6 \pm 0.8 \mathrm{yr}$. The other patient had an $\mathrm{L}_{1}$ congenital myelomeningocele. The average age of the patients was $18.6 \pm 0.7 \mathrm{yr}$ (range 17-22 yr). Preoperative bladder capacity was determined during filling cystometry using a fill rate of $30 \mathrm{ml} / \mathrm{min}$. Bladder capacity was defined as the point at which an uninhibited bladder contraction occurred or the intravesical pressure reached $40 \mathrm{cmH}_{2} \mathrm{O}$ pressure, whichever came first. Before surgery, all patients were being treated with at least one anticholinergic agent for their neurogenic bladders (Table 1). In addition, bladder tissue was obtained from eight organ donors from the National Disease Research Institute (Table 2). Tissue was extirpated as soon as possible after cessation of circulation, immersed in Viaspan (Belzer UW; Dupont Pharma) cold storage solution [composed of the following (g/l): 50 pentafraction, 35.83 lactobionic acid, 3.4 potassium phosphate monobasic, 1.23 magnesium sulfate heptahydrate, 17.83 raffinose pentahydrate, 1.34 adenosine, 0.136 allopurinol, 0.922 total glutathione, 5.61 potassium hydroxide, $\mathrm{pH}$ adjusted to 7.4 with sodium hydroxide or hydrochloric acid], and shipped to the laboratory by courier on wet ice. Six of the eight donors spent time on life support. Experiments were typically carried out the day after procurement in the organ donors and on the same day in the patients with neurogenic bladder.

\section{Muscle strips}

Multiple bladder smooth muscle strips approximately $2 \times 8 \mathrm{~mm}$ (mucosa free) were dissected from the specimen under fourfold magnification such that the direction of the smooth muscle bundles was primarily aligned along the length of the strip. Strips were stretched slowly to $1.0 \mathrm{~g}$ of isometric tension in tissue baths containing $15 \mathrm{ml}$ of modified Tyrode solution ( $125 \mathrm{mM} \mathrm{NaCl}, 2.7 \mathrm{mM} \mathrm{KCl}, 0.4 \mathrm{mM} \mathrm{NaH}_{2} \mathrm{PO}_{4}, 1.8 \mathrm{mM} \mathrm{CaCl}_{2}, 0.5 \mathrm{mM}$ $\mathrm{MgCl}_{2}, 23.8 \mathrm{mM} \mathrm{NaHCO}_{3}$, and $5.6 \mathrm{mM}$ glucose) and equilibrated with $95 \% \mathrm{O}_{2}-5 \% \mathrm{CO}_{2}$ at $37^{\circ} \mathrm{C}$. The strips were tested for their ability to contract in response to electric field stimulation using bipolar platinum electrodes oriented $1 \mathrm{~cm}$ apart along the length of the strip and a stimulus intensity of $8 \mathrm{~V}, 30 \mathrm{~Hz}, 1$-ms duration. Strips that did not contract in response to this electric field stimulation were not used in the analysis. 


\section{Carbachol dose response}

After equilibration to the bath solution for $30 \mathrm{~min}$, separate groups of bladder strips ( $n=3-$ 8) were incubated for $30 \mathrm{~min}$ in the presence or absence of selected concentrations of subtype-selective muscarinic receptor antagonists: methoctramine $(0.1,1.0$, and $10 \mu \mathrm{M}), p$ fluoro-hexahydrosiladifenadol (p-F-HHSiD, $0.1,1.0$, and $10 \mu \mathrm{M}$ ), and darifenacin $(0.03$ $\mu \mathrm{M})$. Each muscle strip was used as either an antagonist-free control or exposed to one concentration of antagonist, and thus each strip only underwent one cumulative doseresponse curve. Dose-response curves were derived from the peak tension developed after cumulative addition of carbachol in one-half log increments $(10 \mathrm{nM}$ to $1 \mathrm{mM}$ final bath concentration). $\mathrm{An}_{\mathrm{EC}_{50}}$ value for each strip was determined from a nonlinear least squares sigmoidal curve fit of the data (Origin, OriginLab, Northampton, MA). Dose ratios were determined based on the average of the $\mathrm{EC}_{50}$ values of antagonist-free strips $(n=3-8)$. The $\mathrm{EC}_{50}$ values determined in the presence of antagonist were used to generate Schild plots to calculate antagonist $\mathrm{pA}_{2}$ values for each individual patient specimen (3). If the slope of the Schild plot was not significantly different from unity, the slope of the Schild plot was constrained to unity to calculate the $\mathrm{p} K_{\mathrm{b}}$ value. Not all of the antagonists could be tested in all of the specimens due to insufficient specimen size.

\section{Statistical and data analysis}

Results are reported as means \pm SE or $95 \%$ confidence intervals for affinity values. Statistically significant differences in the affinity values and departure from unity in the slopes derived from the Schild plots were determined using the $95 \%$ confidence intervals.

\section{RESULTS}

Preoperative bladder capacity in the neurogenic bladder patients averaged $202 \pm 41 \mathrm{ml}$ (range 63-360). Of the seven patients with neurogenic bladder, six had uninhibited detrusor contractions during filling. The average uninhibited bladder contraction was $77 \pm 21 \mathrm{cmH}_{2} 0$ (range 30-140). The other patient reached $40 \mathrm{cmH}_{2} 0$ pressure before an uninhibited contraction occurred; thus filling was stopped and that infused volume was defined as bladder capacity. At the concentrations used, the inhibition of in vitro contraction by all of the antagonists was surmountable by carbachol, and thus all behaved as competitive antagonists. The affinity of the $\mathrm{M}_{3}$ selective antagonist darifenacin or p-F-HHSiD was determined in six of the seven specimens (Fig. 1, patients 2-7). The affinities were consistent with $\mathrm{M}_{2}$-mediated contractions in four of these six specimens (patients 3, 5, 6, and 7), intermediate between $\mathrm{M}_{2}$ and $\mathrm{M}_{3}$ in one specimen (patient 2), and consistent with $\mathrm{M}_{3}$-mediated contractions in one specimen (patient 4). One of these six neurogenic bladder specimens (patient 3 ) and the other neurogenic specimen (patient 1) were tested with the $\mathrm{M}_{2}$-selective antagonist methoctramine, and low affinities were found for both, consistent with $\mathrm{M}_{3}$-mediated contractions. There was no striking relationship between antagonist affinity and preoperative bladder capacity, level of spinal injury, time after injury, or preoperative medications.

In five bladder specimens from the organ donors (Fig. 2, donors 3-6 and 8), the affinity of both p-F-HHSiD and darifenacin was determined. In four of the five (donors 4-6 and 8), the affinity of p-F-HHSiD was within the reported range for $\mathrm{M}_{2}$-mediated contractions, while the affinity of darifenacin was not different from the range of affinities reported for the $\mathrm{M}_{3}$ subtype. In the other specimen (donor 3), the affinity of p-F-HHSiD was within the reported $M_{2}$ range and was intermediate between $M_{2}$ and $M_{3}$ range for darifenacin. In one tissue, only p-F-HHSiD was used (donor 1 ) and had an affinity consistent with $\mathrm{M}_{3}$ receptors mediating contraction. In one tissue (donor 7), only darifenacin was used, and an affinity not different from the $\mathrm{M}_{3}$ range was found. In one specimen (donor 2), p-F-HHSiD and 
methoctramine were used; the p-F-HHSiD affinity was consistent with $\mathrm{M}_{2}$ receptors, while the methoctramine affinity was consistent with $\mathrm{M}_{3}$ receptors mediating contraction. Strikingly, the methoctramine affinity was low (consistent with $\mathrm{M}_{3}$-mediated contractions) in all specimens tested (patients 1 and 3 and donors 2 and 4). In every study we have previously performed, with the single exception of rat bladder after selective alkylation of $\mathrm{M}_{3}$ receptors in the presence of isoproterenol (12), we have always found a low methoctramine affinity consistent with $\mathrm{M}_{3}$ receptors mediating contraction. After confirming this in two human specimens from each group, we did not continue to determine the affinity of methoctramine using this limited patient and donor tissue.

Table 3 provides a summary of the antagonist affinity data.

\section{DISCUSSION}

Human detrusor contractions are thought to be mediated by the $\mathrm{M}_{3}$ receptor subtype. This assumption is based in part on data from animal studies and very limited data in human tissue $(18,24,30,36,37)$. Our study is the first to demonstrate that in individuals with a neurogenic bladder dysfunction from spinal cord injury or myelodysplasia, detrusor contractions can also be mediated by the $\mathrm{M}_{2}$ muscarinic receptor subtype. This was also seen in certain bladders from organ donors.

Bladder contraction occurs from ACh-induced excitation of postjunctional muscarinic cholinergic receptors on bladder smooth muscle. Subtype-selective antimuscarinic agents are available that are at least 10 -fold selective for each of the $\mathrm{M}_{1}-\mathrm{M}_{3}$ subtypes $(15,16)$. The MT3 toxin is at least 30 -fold selective for the $\mathrm{M}_{4}$ subtype $(15,16,31)$. No $\mathrm{M}_{5}$-selective antagonists are currently available. $\mathrm{M}_{1}$ receptors have a high affinity for pirenzepine (PZP), a low affinity for methoctra-mine, and an intermediate affinity for p-F-HHSiD. $\mathrm{M}_{2}$ receptors have a high affinity for methoctramine and a low affinity for PZP and p-F-HHSiD. $\mathrm{M}_{3}$ receptors have a high affinity for 4-diphenlacetoxy- $N$-methylpiperidine methiodide (4DAMP), darifenacin, and p-F-HHSiD, an intermediate affinity for PZP, and a low affinity for methoctramine (15). Affinity values derived from Schild plot analysis of the inhibition of carbachol-induced contractions of the rat urinary bladder are consistent with $\mathrm{M}_{3}$ receptors mediating contraction $(10,49)$. This is also consistent with the response seen in other animal models demonstrating that, although $\mathbf{M}_{2}$ receptors are more abundant $(27,49)$, it is the $\mathrm{M}_{3}$ receptor subtype that is important in the control of bladder contractions across a range of species.

Muscarinic receptor subtypes have been analyzed in human bladder using several different approaches. Binding studies in human bladder as well as cultured human bladder smooth muscle cells have demonstrated greater numbers of $\mathrm{M}_{2}$ than $\mathrm{M}_{3}$ receptors (27, 28, 32, 33, 39). The mRNA encoding $M_{2}$ and $M_{3}$ has been reported to be present in equal amounts (50). With the use of antibodies to the muscarinic subtypes, $\sim 80 \%$ of precipitable receptors are $\mathrm{M}_{2}$, with the rest mainly $\mathrm{M}_{3}(49)$. There are limited functional data from human bladder. Muscarinic receptor stimulation of human bladder tissue induces phosphatidyl inositol (PI) hydrolysis $(2,39,48)$, which is consistent with involvement of the $M_{3}$ subtype because $M_{1}$, $\mathrm{M}_{3}$, and $\mathrm{M}_{5}$ subtypes preferentially couple to PI turnover. This is further supported by a study similar to ours using "normal" human bladders. In these bladder strips, darifenacin had a high $\mathrm{pA}_{2}$ value similar to that for guinea pig bladder, with low affinities of methoctramine and pirenzepine. The authors concluded that contraction in human bladder is mediated through $\mathrm{M}_{3}$ receptors, although the exact source of this human tissue and patient characteristics were not specified in this abstract (37). Similarly, in a series of bladder specimens taken from 10 males and 11 females undergoing cystectomy for bladder cancer, the affinities of six different muscarinic antagonists (PZP, methoctramine, 4-DAMP, 
tropicamide, oxybutynin, and tolterodine) were consistent with $\mathrm{M}_{3}$-mediated contractions (18).

Studies in normal bladders from all species studied to date indicate that the $\mathrm{M}_{3}$ subtype mediates bladder contraction. These determinations are based on the assumption that only one of the receptor subtypes mediates the response. In some of our pathological human bladder specimens from patients with neurogenic bladder dysfunction or organ donors, it appears that both $\mathrm{M}_{2}$ and $\mathrm{M}_{3}$ receptors may be mediating the contractile response depending on which subtype-selective antagonist was used. We interpret the apparent contradictory data (i.e., a low p-F-HHSiD affinity indicating $\mathrm{M}_{2}$-mediated contractions together with a low methoctramine affinity indicating $\mathrm{M}_{3}$-mediated contractions) to be consistent with a scenario in which either the $\mathrm{M}_{2}$ or the $\mathrm{M}_{3}$ receptor can mediate contraction. When the $\mathrm{M}_{2}$ receptor is inhibited by methoctramine, the $\mathrm{M}_{3}$ receptor mediates contraction. When the concentration of methoctramine is high enough to block both the $\mathrm{M}_{2}$ and the $\mathrm{M}_{3}$ receptor, contraction is inhibited. This would yield an affinity consistent with blockade of the least sensitive receptor to methoctramine, in this case the $\mathrm{M}_{3}$. The converse is also true, i.e., p-FHHSiD would not affect contraction until both $\mathrm{M}_{2}$ and $\mathrm{M}_{3}$ receptors are inhibited and thus a low affinity would be obtained. In five of the organ donor specimens, the affinity of two different $\mathrm{M}_{3}$-selective antagonists (darifenacin and p-FHHSiD) was determined. In four of these five, an affinity consistent with $\mathrm{M}_{2}$ receptors was found using the less selective antagonist (p-F-HHSiD), whereas the affinity of the antagonist with a greater selectivity for $\mathrm{M}_{3}$ receptors (darifenacin) was high, consistent with $\mathrm{M}_{3}$ receptors mediating contractions. The relative selectivity of these two antagonists may offer some explanation of these findings.

There are multiple reports of an $\mathrm{M}_{2}$ receptor contribution to bladder contraction under certain experimental conditions or in different pathological states. Bilateral removal of the major pelvic ganglia in rats renders the bladder denervated because unlike other mammalian species, the adult rat bladder does not contain intramural ganglia $(25,46)$. Because these bladders cannot empty on their own, they become hypertrophic within $24 \mathrm{~h}$ after denervation even though they are emptied with manual external abdominal pressure twice a day. In denervated bladders, the affinity of subtype-selective antimuscarinic receptor drugs to inhibit carbachol-induced contractions is consistent with $\mathrm{M}_{2}$ or a combination of $\mathrm{M}_{2}$ - and $\mathrm{M}_{3}$-mediated bladder contractions, while nondenervated sham-operated control bladders display affinities consistent with $\mathrm{M}_{3}$-mediated contractions. After denervation, there is a $60 \%$ increase in $\mathrm{M}_{2}$ receptor density with no change in $\mathrm{M}_{3}$ receptor density compared with sham-operated controls (11). $\mathrm{M}_{2}$ receptors also participate in contraction of the bladder from rats with a $T_{9}$ level spinal cord injury who do not spontaneously regain the ability to urinate (7). Rats with the $T_{9}$ level injury who were able to spontaneously urinate and control animals demonstrate bladder contractions mediated by the $\mathrm{M}_{3}$ receptor subtype. Other conditions affecting smooth muscle in which there is $\mathrm{M}_{2}$-mediated contraction include experimental esophagitis in cat (41), a model of acute cholecystitis in guinea pig (8), and arterial hypertension (47). In addition, alteration of experimental conditions in smooth muscle studies can shift the subtypes mediating contraction from $\mathrm{M}_{3}$ to $\mathrm{M}_{2}$. This includes inhibition of the sarcoplasmic reticulum ATPase (13) and after inactivation of $\mathrm{M}_{3}$ receptors using the irreversible inhibitor 4-DAMP mustard in an environment of increased intracellular cAMP $(12,29)$.

There are several mechanisms through which $\mathrm{M}_{2}$ receptors may produce bladder contraction. Data obtained after selective alkylation of $\mathrm{M}_{3}$ receptors with 4-DAMP mustard suggest that $\mathrm{M}_{2}$ receptors, through activation of a GTP binding protein associated with inhibition of adenylyl cyclase $\left(\mathrm{G}_{\mathrm{i}}\right)$, may be involved in inhibition of $\beta$-adrenergic receptorinduced relaxation $(12,29)$. Based on cloned receptors expressed in $\mathrm{CHO}$ cells, a particular 
receptor subtype does seem to preferentially couple with one type of G protein. However, there is substantial evidence of significant promiscuity in this coupling mechanism such that, depending on the type of cell and the biochemical state of the cell, a given receptor may be able to couple with several different types of $\mathrm{G}$ proteins so that a single receptor subtype may mediate several different cellular signals $(45,49)$. Whereas $\mathrm{M}_{2}$ receptors are traditionally thought to couple to the $\mathrm{G}_{\mathrm{i}}$ class of GTP binding proteins, we have demonstrated, using a coimmunoprecipitation assay, that $M_{2}$ receptors can also couple to $G_{q}$ in human bladder (49). Thus differential coupling of $\mathrm{M}_{2}$ to different $\mathrm{G}$ proteins under different conditions may alter its effect on bladder tissue. There are several different mechanisms of $\mathrm{M}_{2}$ action, demonstrated in smooth muscle other than the bladder, that may also be active in the detrusor. These include opening of nonselective cation channels, resulting in depolarization and influx of calcium, which is seen in ileum (4), and inhibition of conductance through potassium channels as seen in canine colon (21). $\mathrm{M}_{2}$ receptors could also activate protein kinase $\mathrm{C}$ (PKC) to induce contraction $(21,48)$.

Selective alkylation experiments in mice demonstrates that in most strains, no indirect contractile role for $\mathrm{M}_{2}$ receptors exists $(19,20)$ as can be shown in rat bladder $(12,29)$ and guinea pig ileum (43). This is confirmed by muscarinic receptor subtype knockout experiments in mice. In $\mathrm{M}_{3}$ knockout mice, very little residual $\mathrm{M}_{2}$-mediated contractions are found (35), and in $\mathrm{M}_{2}$ knockout mice, maximal contractions to carbachol in bladder are not reduced and carbachol potency is only slightly decreased (42). The regulation of the interplay between $\mathrm{M}_{2}$ - and $\mathrm{M}_{3}$-mediated contractions is not clear; however, receptor density may play a role. After denervation in the rat, there is an increase in the number of $\mathrm{M}_{2}$ receptors but not $M_{3}$ (11). There is also evidence that the $M_{2} / M_{3}$ interaction is regulated by intracellular calcium. Low levels of muscarinic stimulation and hence low levels of calcium induce a translocation in PKC to the membrane, while at greater levels of receptor stimulation PKC activation is inhibited (40). We have shown, using combinations of $\mathrm{M}_{2^{-}}$ and $\mathrm{M}_{3}$-selective antagonists, that there is no synergy between these subtypes in normal rat bladder contraction. However, in the denervated, hypertrophied bladder there is a synergistic interaction between the two subtypes in that the contractile response from the combination of $\mathrm{M}_{2}$ and $\mathrm{M}_{3}$ subtypes is greater than what would be predicted from the sum of each subtype acting alone (13).

As a result of using specimens from patients with neurogenic bladder dysfunction, our results differ from previous published results in human bladder that concluded that the $\mathrm{M}_{3}$ subtype mediates bladder contraction $(18,37)$. Some of our donor tissue also shows $\mathrm{M}_{2}$ mediated contractions. While it is not likely that bladder hypertrophy or neurogenic lesions are responsible for this finding, one explanation is that the physiology of this tissue is different from normal because of the transport solution and ischemia or anoxia. Another possible reason is due to bladder inactivity while the donor was on life support or due to long transport times. An additional explanation may be that we determined antagonist affinities in each individual patient specimen as opposed to averaging results from all individuals. Many studies in the past have correlated the affinities of antagonists in inhibition of bladder contraction with their affinities for each of the five muscarinic receptor subtypes expressed in clonal cell lines, assuming that the subtype that gives the highest correlation coefficient mediates bladder contraction $(1,18,22,29)$. This method gives the same weight to drugs with no subtype selectivity as those that are highly selective. Often this type of analysis yields similar significant correlations for more than one subtype. An underlying assumption is that a single subtype mediates contraction. Our data and others indicate that both $\mathrm{M}_{2}$ and $\mathrm{M}_{3}$ muscarinic receptor subtypes are involved in mediating contraction of bladder smooth muscle $(9,12,26,29)$. Another issue in determining the muscarinic receptors that mediates normal human bladder contraction is that tissue is taken at the time of surgery performed for some pathological process, so whether this tissue truly 
represents normal bladder must be questioned. This also includes organ transplant donor controls, some of which we found in this investigation to have $\mathrm{M}_{2}$-mediated bladder contractions. A major difference in our study from those published previously is that we are looking at neurogenic bladder, which is different from that used in other studies. Irrespective of the physiological changes from the neurological injury, another factor to consider in these patients may be the concomitant use of antimuscarinic and other medications.

Prior studies described above have used inactivation of the $\mathrm{M}_{3}$ receptor with 4-DAMP mustard to produce $\mathrm{M}_{2}$-mediated contractions $(12,24,29)$. At least six of the seven patients were on long-term antimuscarinics to treat their neurogenic bladders before surgery (see Table 1 for specifics). Although these medications do not covalently inactivate the muscarinic receptor like 4-DAMP mustard does, it is possible that the long-term use of muscarinic antagonists may serve to modulate the $\mathrm{M}_{3}$ or $\mathrm{M}_{2}$ contractile response. Chronic atropine treatment may increase muscarinic receptor density; however, this is dependent on the method of drug administration. When atropine was administered for 14 days through an osmotic pump at $5 \mathrm{mg} \cdot \mathrm{kg}^{-1} \cdot \mathrm{day}^{-1}$ to rats, we found that muscarinic receptor density increased by $\sim 43 \%$ (34). In another study in which atropine was given for 14 days by daily intraperitoneal injection $(20 \mathrm{mg} / \mathrm{kg})$, we found that no increase in muscarinic receptor density occurred (17). The effect of the antimuscarinics on the density of muscarinic receptors in our patients is unknown. Nonetheless, the only issue that this would cloud is whether contraction in the untreated neurogenic bladder is predominantly mediated by the $\mathrm{M}_{3}$ receptor. Our data show that bladder contractions in these patients are mediated by the $\mathrm{M}_{2}$ receptor, whether it is due to the physiological changes of the injury or due to any contribution of their concomitant medications. Another factor in our neurogenic bladder patients may be the effect of functional bladder outlet obstruction from vesicosphincter dyssynergia. Bladder outlet obstruction for 3 days in the rat yields a hypertrophied bladder, some degree of functional denervation, and an $\mathrm{M}_{2}$-mediated component of contraction (9).

Our data may have clinical implications. In patients with a suprasacral spinal cord injury, some of the bladder contraction can be $\mathrm{M}_{2}$ mediated. Thus in these patients, addition of a relatively selective $M_{2}$ antagonist or a drug that has both $M_{2}$ and $M_{3}$ blocking activity might be expected to be more effective in increasing bladder capacity than one that is predominantly $\mathrm{M}_{3}$ selective. However, intravenous administration of the highly $\mathrm{M}_{3}$ selective antagonist darifenacin has been shown to effectively suppress unstable bladder contractions provoked by rapid fluid infusion $(50-100 \mathrm{ml}$ infused at $20 \mathrm{ml} / \mathrm{s}$ ) in a group of eight male patients with suprasacral spinal cord injury (14). An advantage of an $\mathrm{M}_{2^{-}}$ selective agent would be less dry mouth because salivation is primarily mediated by $\mathrm{M}_{3}$ receptors (38). On the other hand, an $\mathrm{M}_{2}$-selective antagonist might be expected to produce increased cardiac side effects because the $\mathrm{M}_{2}$ receptor mediates the effects of the vagus nerve on the heart. A larger unanswered question is whether these results are applicable to the large number of patients who are clinically neurologically intact and use antimuscarinic medications for overactive bladder. One theory of overactive bladder in otherwise neurologically intact individuals is that of partial detrusor denervation (6). In our rat model of bladder denervation, there is a shift in the muscarinic receptor subtypes responsible for bladder contraction from $\mathrm{M}_{3}$ to $\mathrm{M}_{2}$. In these patients who have decentralization of their bladders, there was also a shift in the muscarinic receptor subtype mediating contraction from $M_{3}$ to $M_{2}$. These data indicate that if there is some element of denervation in patients with overactive bladder, then there might also be a shift from $\mathrm{M}_{3}$ - to $\mathrm{M}_{2}$-mediated contraction. This deserves further investigation.

Whereas normal detrusor contractions are thought to be mediated by the $\mathrm{M}_{3}$ receptor subtype, in patients with neurogenic bladder dysfunction and certain organ donors, contractions can be mediated by the $\mathrm{M}_{2}$ muscarinic receptor subtype. These findings 
challenge the assumption on which medical therapy is based for treatment of patients with voiding dysfunction. There may also be implications for drug development. If the change in function and number of receptor subtypes in denervated bladder is a common phenomenon in other pathological states, then the therapies developed for the treatment of these conditions based on the effect in normal tissue may be clinically ineffective. Results from clinical trials with the $\mathrm{M}_{3}$-selective receptor antagonist darifenacin may help to clarify the relative importance of $\mathrm{M}_{2}$ and $\mathrm{M}_{3}$ receptors in overactive bladder. To our knowledge, there are currently no $\mathrm{M}_{2}$ subtype-selective antagonists in development for clinical use. Our data also point out the variability between individual patient response to selective antimuscarinic therapy. Thus the present data indicate that different individuals or groups of patients might benefit from different antimuscarinic profiles, i.e., $\mathrm{M}_{3}$-selective, $\mathrm{M}_{2}$-selective, or nonselective drugs. Caution should be used therefore in pooling data from different patients and assuming the average results represent all patients. Currently, clinical trials require this pooling of patient data because there is currently no way of stratifying patients a priori into separate groups based on their potential clinical response to antimuscarinic drugs with different selectivity profiles.

\section{Acknowledgments}

This research was supported by National Institute of Diabetes and Digestive and Kidney Diseases Grant DK-43333.

\section{REFERENCES}

1. Alberts P. Classification of the presynaptic muscarinic receptor subtype that regulates ${ }^{3} \mathrm{H}-$ acetylcholine secretion in the guinea pig urinary bladder in vitro. J Pharmacol Exp Ther. 1995; 274:458-468. [PubMed: 7616431]

2. Andersson KE, Holmquist F, Fovaeus M, Hedlund H, Sundler R. Muscarinic receptor stimulation of phosphoinositide hydrolysis in the human isolated urinary bladder. J Urol. 1991; 146:1156-1159. [PubMed: 1654463]

3. Arunlakshan O, Schild HO. Some qualitative uses of drug antagonists. Br J Pharmacol. 1959; $14: 48-58$.

4. Bolton TB, Zholos AV. Activation of $\mathrm{M}_{2}$ muscarinic receptors in guinea-pig ileum opens cationic channels modulated by $\mathrm{M}_{3}$ muscarinic receptors. Life Sci. 1997; 60:1121-1128. [PubMed: 9121356]

5. Bonner TI, Buckley NJ, Young AC, Brann MR. Identification of a family of muscarinic acetylcholine receptor genes. Science. 1987; 237:527-532. [PubMed: 3037705]

6. Brading AF. A myogenic basis for the overactive bladder. Urology. 1997; 50:57-67. discussion 6873. [PubMed: 9426752]

7. Braverman A, Legos J, Young W, Luthin G, Ruggieri M. $\mathrm{M}_{2}$ receptors in genito-urinary smooth muscle pathology. Life Sci. 1999; 64:429-436. [PubMed: 10069506]

8. Braverman AS, Bartula LL, Myers SI, Parkman HP, Ruggieri MR. Inflammation changes the muscarinic receptor subtype and signal transduction pathway that mediates gallbladder contraction (Abstract). Gastroenterology. 2000; 118:A197.

9. Braverman AS, Karlovsky M, Pontari MA, Ruggieri MR. Aging and hypertrophy change the muscarinic receptor subtype mediating bladder contraction from $\mathrm{M}_{3}$ towards $\mathrm{M}_{2}$. J Urol. 2002; 167:170.

10. Braverman AS, Kohn IJ, Luthin GR, Ruggieri MR. Prejunctional M-1 facilitory and M-2 inhibitory muscarinic receptors mediate rat bladder contractility. Am J Physiol Regul Integr Comp Physiol. 1998; 274:R517-R523.

11. Braverman AS, Luthin GR, Ruggieri MR. $M_{2}$ muscarinic receptor contributes to contraction of the denervated rat urinary bladder. Am J Physiol Regul Integr Comp Physiol. 1998; 275:R1654R1660. 
12. Braverman AS, Ruggieri MR. Selective alkylation of rat urinary bladder muscarinic receptors with 4-DAMP mustard reveals a contractile function for the $\mathrm{M}_{2}$ muscarinic receptor. J Recept Signal Transduct Res. 1999; 19:819-833. [PubMed: 10349596]

13. Braverman AS, Tallarida RJ, Ruggieri MR Sr. Interaction between muscarinic receptor subtype signal transduction pathways mediating bladder contraction. Am J Physiol Regul Integr Comp Physiol. 2002; 283:R663-R668. [PubMed: 12185001]

14. Bycroft, J.; Leaker, B.; Wood, S.; Knight, S.; Shah, J.; Craggs, M. The effect of darifenacin on neurogenic detrusor overactivity in patients with spinal cord injury. Proc 33rd Int Continence Soc Annu Mtg Florence; Italy. 2003. p. 74-76.

15. Caulfield MP. Muscarinic receptors - characterization, coupling and function. Pharmacol Ther. 1993; 58:319-379. [PubMed: 7504306]

16. Caulfield MP, Birdsall NJ. International Union of Pharmacology. XVII. Classification of muscarinic acetylcholine receptors. Pharmacol Rev. 1998; 50:279-290. [PubMed: 9647869]

17. Cawley TA Jr, Shickley TJ, Ruggieri MR, Luthin GR. Effect of chronic neuroleptic treatment on central and peripheral muscarinic receptors. J Pharmacol Exp Ther. 1993; 267:134-139. [PubMed: 7901388]

18. Chess-Williams R, Chapple CR, Yamanishi T, Yasuda K, Sellers DJ. The minor population of $\mathrm{M}_{3^{-}}$ receptors mediate contraction of human detrusor muscle in vitro. J Auton Pharmacol. 2001; 21:243-248. [PubMed: 12123469]

19. Choppin A. Muscarinic receptors in isolated urinary bladder smooth muscle from different mouse strains. Br J Pharmacol. 2002; 137:522-528. [PubMed: 12359634]

20. Choppin A, Eglen RM. Pharmacological characterization of muscarinic receptors in mouse isolated urinary bladder smooth muscle. Br J Pharmacol. 2001; 133:1035-1040. [PubMed: 11487513]

21. Cole WC, Carl A, Sanders KM. Muscarinic suppression of $\mathrm{Ca}^{2+-}$ dependent $\mathrm{K}$ current in colonic smooth muscle. Am J Physiol Cell Physiol. 1989; 257:C481-C487.

22. D'Agostino G, Barbieri A, Chiossa E, Tonini M. M4 muscarinic autoreceptor-mediated inhibition of ${ }^{3} \mathrm{H}$-acetylcholine release in the rat isolated urinary bladder. J Pharmacol Exp Ther. 1997; 283:750-756. [PubMed: 9353395]

23. Durant PA, Shankley NP, Welsh NJ, Black JW. Pharmacological analysis of agonist-antagonist interactions at acetylcholine muscarinic receptors in a new urinary bladder assay. Br J Pharmacol. 1991; 104:145-150. [PubMed: 1786508]

24. Fetscher C, Fleichman M, Schmidt M, Krege S, Michel MC. M(3) muscarinic receptors mediate contraction of human urinary bladder. Br J Pharmacol. 2002; 136:641-643. [PubMed: 12086973]

25. Gabella G, Uvelius B. Urinary bladder of rat: fine structure of normal and hypertrophic musculature. Cell Tissue Res. 1990; 262:67-79. [PubMed: 2257617]

26. Gillberg PG, Sundquist S, Nilvebrant L. Comparison of the in vitro and in vivo profiles of tolterodine with those of subtype-selective muscarinic receptor antagonists. Eur J Pharmacol. 1998; 349:285-292. [PubMed: 9671109]

27. Goepel M, Gronewald A, Krege S, Michel MC. Muscarinic receptor subtypes in porcine detrusor: comparison with humans and regulation by bladder augmentation. Urol Res. 1998; 26:149-154. [PubMed: 9631949]

28. Harriss DR, Marsh KA, Birmingham AT, Hill SJ. Expression of muscarinic $\mathrm{M}_{3}$-receptors coupled to inositol phospholipid hydrolysis in human detrusor cultured smooth muscle cells. J Urol. 1995; 154:1241-1245. [PubMed: 7637095]

29. Hegde SS, Choppin A, Bonhaus D, Briaud S, Loeb M, Moy TM, Loury D, Eglen RM. Functional role of $\mathrm{M}_{2}$ and $\mathrm{M}_{3}$ muscarinic receptors in the urinary bladder of rats in vitro and in vivo. $\mathrm{Br} \mathrm{J}$ Pharmacol. 1997; 120:1409-1418. [PubMed: 9113359]

30. Ikeda K, Kobayashi S, Suzuki M, Miyata K, Takeuchi M, Yamada T, Honda K. M(3) receptor antagonism by the novel antimuscarinic agent solifenacin in the urinary bladder and salivary gland. Naunyn Schmiedebergs Arch Pharmacol. 2002; 366:97-103. [PubMed: 12122494]

31. Jerusalinsky D, Kornisiuk E, Alfaro P, Quillfeldt J, Ferreira A, Rial VE, Duran R, Cervenansky C. Muscarinic toxins: novel pharmacological tools for the muscarinic cholinergic system. Toxicon. 2000; 38:747-761. [PubMed: 10695963] 
32. Kiwamoto H, Ma FH, Higashira H, Park YC, Kurita T. Identification of muscarinic receptor subtypes of cultured smooth muscle cells and tissue of human bladder body. Int J Urol. 2001; 8:557-563. [PubMed: 11737484]

33. Kondo S, Morita T, Tashima Y. Muscarinic cholinergic receptor subtypes in human detrusor muscle studies by labeled and non labeled pirenzepine, AFDX-116 and 4-DAMP. Urol Int. 1995; 54:150-153. [PubMed: 7604457]

34. Levin RM, Ruggieri MR, Lee W, Wein AJ. Effect of chronic atropine administration on the rat urinary bladder. J Urol. 1988; 139:1347-1349. [PubMed: 3373612]

35. Matsui M, Motomura D, Karasawa H, Fujikawa T, Jiang J, Komiya Y, Takahashi S, Taketo MM. Multiple functional defects in peripheral autonomic organs in mice lacking muscarinic acetylcholine receptor gene for the $\mathrm{M}_{3}$ subtype. Proc Natl Acad Sci USA. 2000; 97:9579-9584. [PubMed: 10944224]

36. Miyamae K, Yoshida M, Murakami S, Iwashita H, Ohtani M, Masunaga K, Ueda S. Pharmacological effects of darifenacin on human isolated urinary bladder. Pharmacology. 2003; 69:205-211. [PubMed: 14624061]

37. Newgreen DT, Taylor AM. Characterisation of functional muscarinic receptors in human bladder (Abstract). Br J Pharmacol. 1996; 119:45P.

38. Nilvebrant L, Andersson KE, Gillberg PG, Stahl M, Sparf B. Tolterodine-a new bladder-selective antimuscarinic agent. Eur J Pharmacol. 1997; 327:195-207. [PubMed: 9200560]

39. Ruggieri MR, Bode DC, Levin RM, Wein AJ. Muscarinic receptor subtypes in human and rabbit bladder. Neurourol Urodyn. 1987; 6:119-128.

40. Sohn UD, Chiu TT, Bitar KN, Hillemeier C, Behar J, Biancani P. Calcium requirements for acetylcholine-induced contraction of cat esophageal circular muscle cells. Am J Physiol Gastrointest Liver Physiol. 1994; 266:G330-G338.

41. Sohn UD, Harnett KM, Cao W, Rich H, Kim N, Behar J, Biancani P. Acute experimental esophagitis activates a second signal transduction pathway in cat smooth muscle from the lower esophageal sphincter. J Pharmacol Exp Ther. 1997; 283:1293-1304. [PubMed: 9400005]

42. Stengel PW, Yamada M, Wess J, Cohen ML. M(3)-receptor knockout mice: muscarinic receptor function in atria, stomach fundus, urinary bladder, and trachea. Am J Physiol Regul Integr Comp Physiol. 2002; 282:R1443-R1449. [PubMed: 11959688]

43. Thomas EA, Baker SA, Ehlert FJ. Functional role for the $\mathrm{M}_{2}$ muscarinic receptor in smooth muscle of guinea pig ileum. Mol Pharmacol. 1993; 44:102-110. [PubMed: 8393516]

44. Tobin G, Sjogren C. In vivo and in vitro effects of muscarinic receptor antagonists on contractions and release of $\left[{ }^{3} \mathrm{H}\right]$ acetylcholine in the rabbit urinary bladder. Eur J Pharmacol. 1995; 281:1-8. [PubMed: 8566107]

45. Tucek S, Michal P, Vlachova V. Modelling the consequences of receptor-G-protein promiscuity. Trends Pharmacol Sci. 2002; 23:171-176. [PubMed: 11931992]

46. Uvelius B, Gabella G. Intramural neurones appear in the urinary bladder wall following excision of the pelvic ganglion in the rat. Neuro-report. 1995; 6:2213-2216.

47. Van Zwieten PA, Doods HN. Muscarinic receptors and drugs in cardiovascular medicine. Cardiovasc Drugs Ther. 1995; 9:159-167. [PubMed: 7786837]

48. Walsh MP, Horowitz A, Clement-Chomienne O, Andrea JE, Allen BG, Morgan KG. Protein kinase $\mathrm{C}$ mediation of $\mathrm{Ca}^{2+}$-independent contractions of vascular smooth muscle. Biochem Cell Biol. 1996; 74:485-502. [PubMed: 8960355]

49. Wang P, Luthin GR, Ruggieri MR. Muscarinic acetylcholine receptor subtypes mediating urinary bladder contractility and coupling to GTP binding proteins. J Pharmacol Exp Ther. 1995; 273:959-966. [PubMed: 7752101]

50. Yamaguchi O, Shishido K, Tamura K, Ogawa T, Fujimura T, Ohtsuka M. Evaluation of mRNAs encoding muscarinic receptor sub-types in human detrusor muscle. J Urol. 1996; 156:1208-1213. [PubMed: 8709348] 


\section{Spinal Injured Patients}

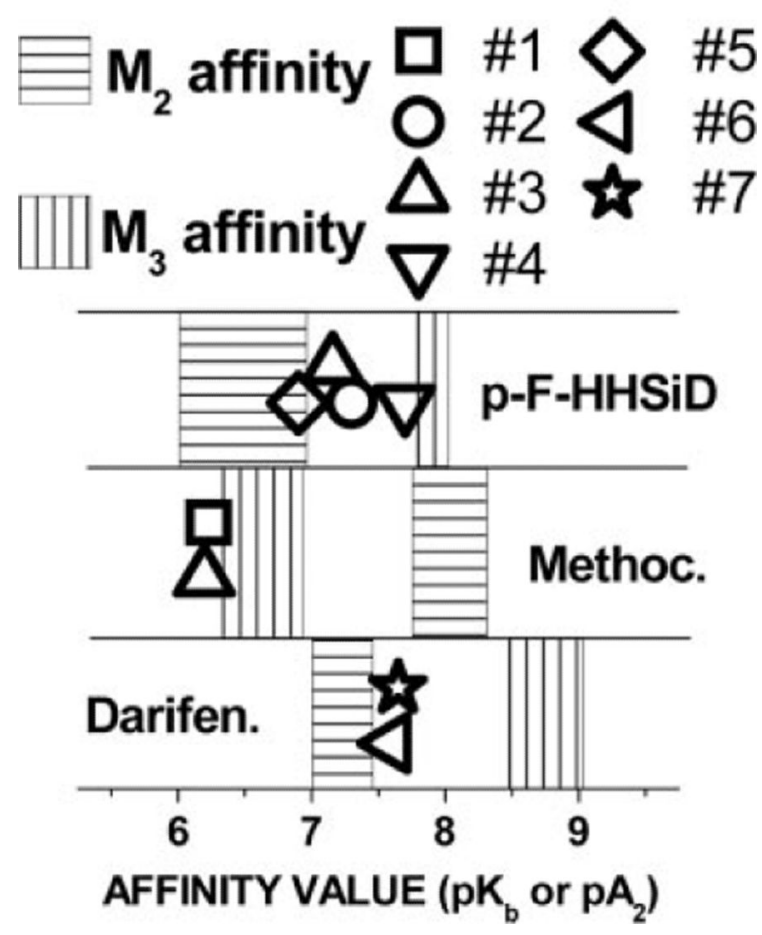

Fig. 1.

Affinity of subtype-selective antimuscarinics for inhibiting carbachol-induced contraction of urinary bladder muscle strips in vitro from spinal injured patients. The shaded areas represent the affinity ranges of antimuscarinics [ $p$-fluoro-hexahydrosiladifenadol (p-FHHSiD), methoctramine (Methoc), and darifenacin (Darifen)] for the individual receptor subtypes reported in the literature $(15,29)$. Reported affinity ranges for the $\mathbf{M}_{2}$ subtype is shaded with horizontal lines, and reported affinity for the $\mathrm{M}_{3}$ subtype is shaded with vertical lines. Symbols refer to the affinities that were determined by Schild analysis of the bladder tissue obtained from the individual patient numbers indicated in Table 1. 


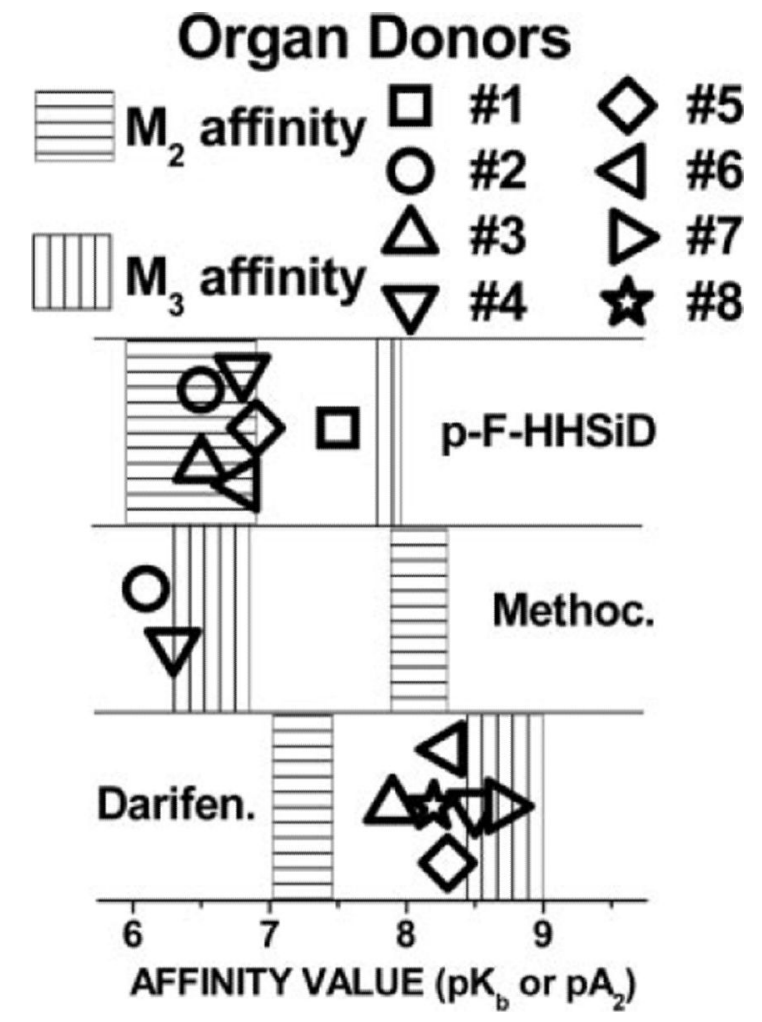

Fig. 2.

Affinity of subtype-selective antimuscarinics for inhibiting carbachol-induced contraction of urinary bladder muscle strips in vitro from organ donors. Notation is the same as indicated for Fig. 1 except characteristics of donor numbers are indicated in Table 2. 


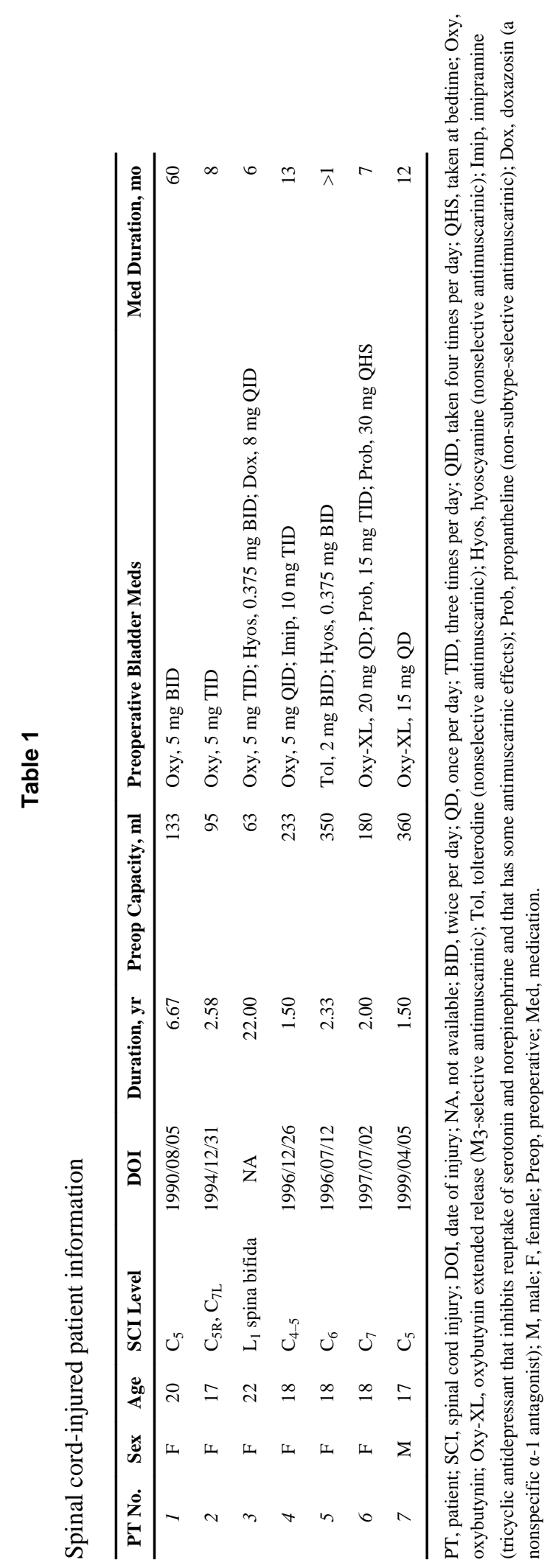

Am J Physiol Regul Integr Comp Physiol. Author manuscript; available in PMC 2012 February 8. 


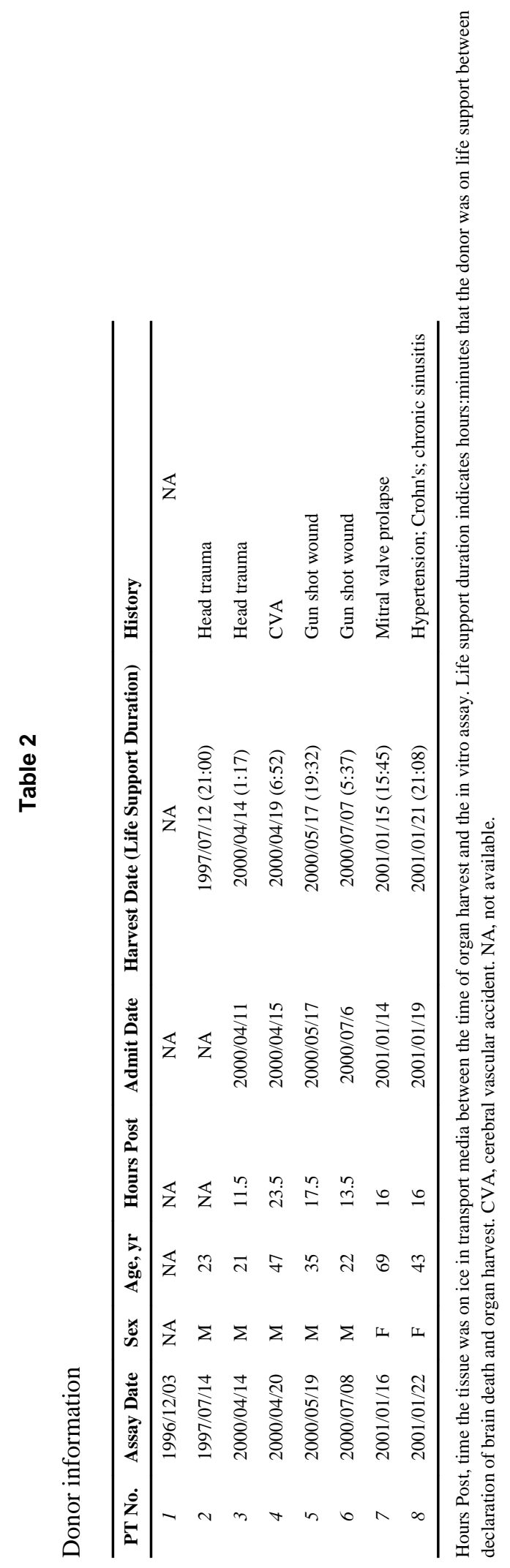

Am J Physiol Regul Integr Comp Physiol. Author manuscript; available in PMC 2012 February 8. 


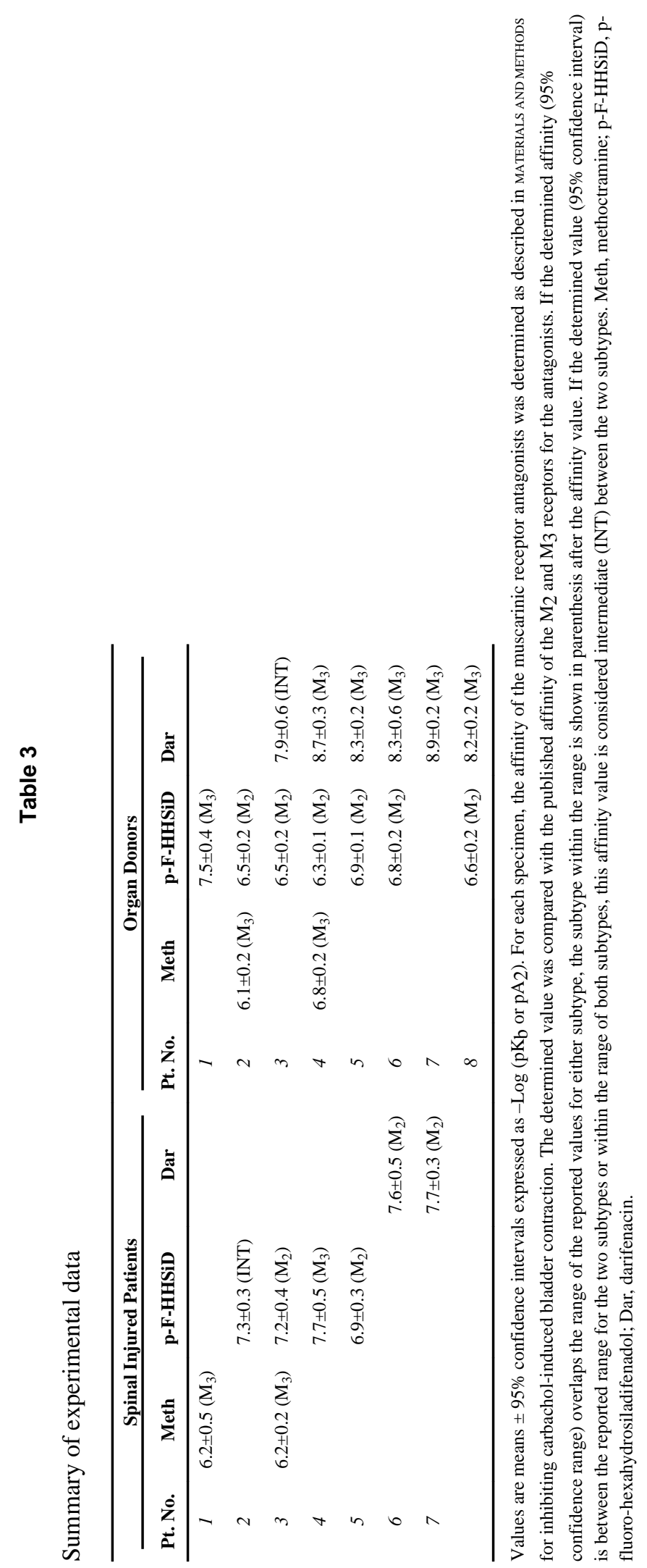

